Article

\title{
Effect of Cultural Conditions on Protease Production by a Thermophilic Geobacillus thermoglucosidasius SKF4 Isolated from Sungai Klah Hot Spring Park, Malaysia
}

\author{
Allison D. Suleiman 1,2, Nor'Aini Abdul Rahman ${ }^{1, *}$, Hidayat Mohd Yusof ${ }^{1}$ (D), \\ Fairolniza Mohd Shariff ${ }^{3}$ and Nur Adeela Yasid ${ }^{4}$ \\ 1 Department of Bioprocess Technology, Faculty of Biotechnology and Biomolecular Sciences, Universiti Putra, \\ Malaysia, Serdang Selangor 43400, Malaysia; allisonsuleiman@yahoo.com (A.D.S.); \\ hidayatmy@gmail.com (H.M.Y.) \\ 2 Department of Food Science and Technology, School of Agriculture and Agricultural Technology, \\ Moddibo Adama University of Technology, Yola 640230, Nigeria \\ 3 Department of Microbiology, Faculty of Biotechnology and Biomolecular Sciences, Universiti Putra Malaysia, \\ Serdang Selangor 43400, Malaysia; fairolniza@upm.edu.my \\ 4 Department of Biochemistry, Faculty of Biotechnology and Biomolecular Sciences, Universiti Putra, \\ Malaysia, Serdang Selangor 43400, Malaysia; adeela@upm.edu.my \\ * Correspondence: nor_aini@upm.edu.my; Tel.: +60-39-769-1945; Fax: +60-39-769-7590
}

Received: 25 February 2020; Accepted: 11 April 2020; Published: 4 June 2020

\begin{abstract}
Major progress in the fields of agriculture, industry, and biotechnology over the years has influenced the quest for a potent microorganism with favorable properties to be used in scientific research and industry. This study intended to isolate a new thermophilic-protease-producing bacterium and evaluate its growth and protease production under cultural conditions. Protease producing bacteria were successfully isolated from Sungai Klah Hot Spring Park in Perak, Malaysia, and coded as SKF4; they were promising protease producers. Based on microscopic, morphological, and 16S rRNA gene analysis, isolate SKF4 was identified as Geobacillus thermoglucosidasius SKF4. The process of isolating SKF4 to grow and produce proteases under different cultural conditions, including temperature, $\mathrm{pH}, \mathrm{NaCl}$ concentration, carbon and nitrogen sources, and incubation time, was explored. The optimum cultural conditions observed for growth and protease production were at 60 to $65^{\circ} \mathrm{C}$ of temperature, pH 7 to 8 , and under $1 \% \mathrm{NaCl}$ concentration. Further, the use of casein and yeast extract as the nitrogen sources, and sucrose and fructose as the carbon sources enhanced the growth and protease production of isolate SKF4. Meanwhile, isolate SKF4 reached maximum growth and protease production at $24 \mathrm{~h}$ of incubation time. The results of this study revealed a new potent strain of thermophilic bacterium isolated from Sungai Klah Hot Spring Park in Perak, Malaysia for the first time. The high production of thermostable protease enzyme by G. thermoglucosidasius SKF4 highlighted the promising properties of this bacterium for industrial and biotechnological applications.
\end{abstract}

Keywords: protease; Geobacillus thermoglucosidasius SKF4; hot spring; Malaysia

\section{Introduction}

Proteolytic enzymes represent one of the major classes of enzymes with commercial importance that are utilized for industrial purposes. Proteases or peptidases are a class of hydrolytic enzymes involved in hydrolyzing the peptide bonds in proteins and catalyze the synthesis of peptides in the 
presence of an organic solvent [1,2]. Rao et al. [3] described the protease enzyme as a hydrolytic enzyme that increases the rate of the splitting of peptides links in other proteins. Based on the range of $\mathrm{pH}$ in which they function, proteases or peptidases can be classified as acidic, alkaline, or neutral, and can be divided into cysteine, serine, and aspartic proteases, and metalloproteases, based on the functional groups present around their active sites [2-4].

Proteases have a key function regarding industrial enzymes in areas such as domestic, industrial, the processing of leather, bioremediation, nutraceutical purposes, healthcare products, development of a kit for diagnosis, and the incrementation of the value in the production for medical purposes [5]. In 2009, an estimated value of $\$ 220$ billion of industrial enzymes was sold worldwide [5]. Thermophilic microorganisms devised adaptation towards growing and surviving in extreme temperatures. They can be divided into the following classes: moderately thermophilic, extremely thermophilic, and hyperthermophilic [6,7]. Therefore, the organisms are capable of being isolated from high temperature terrestrial as well as marine habitats such as volcanic and geothermal escape systems [7]. In recent times, Nazina et al. [8] arranged thermophilic bacteria bacilli that are Gram-positive with rod shape cells and formed endospores to be known as genus Geobacillus. They have a broad distribution and are less difficult to be isolated from the diverse natural environment $[8,9]$. Their thermostable gene products have been increasingly demanded by industries $[10,11]$. Therefore, the study of diversity and phylogenetic relationships within the genus of a new bacterium is not only a matter of significant taxonomy, but is also essential so that its biotechnological potential can be completely exploited.

Geobacillus represents the most common aerobic organisms isolated from hot spring samples. This genus was originally classified under Bacillus; however, the bacteria were regrouped into a distinct genus [12]. Geobacillus species have been isolated from several environments, such as high-temperature oil fields, a corroded pipeline in a very deep well [13], an African hot spring [8], a Russian hot spring, and a marine vent [14]. They are obligate thermophilic organisms that can grow in temperatures ranging from 37 to $75^{\circ} \mathrm{C}$ and grow optimally between 55 and $65^{\circ} \mathrm{C}$. In this regard, most members of the genus are found in warm biotopes, such as most soil environments, heaps of compost, oil fields, and geothermal zones [12,15]. Unexpectedly, these organisms can also be discovered in low-temperature habitats, such as soil that has never been subjected to extreme temperatures, or at the lowest part of the sea $[12,16]$.

One of the natural environments wherein thermophilic bacteria can be widely found is the hot spring. Hot springs are where hot geothermal water comes out from the ground. They can be found in every part of the world, including underneath the oceans and seas [15]. Studies based on molecular phylogenetic approaches using $16 \mathrm{~S}$ rRNA to investigate different bacteria found in the hot spring have been undertaken lately [15]. Thermophilic bacteria have been characterized by phenotypic and genotypic means from numerous geothermal regions of the world [15]. Saxena et al. [17] and Sahay et al. [18] described thermal springs as being a very strong habitat for a potential microorganism with unique enzymes, molecules, and genes, which could advance applications in medicine, agriculture, and industry.

Geobacillus thermoglucosidasius (also known as G. thermoglucosidans) are endospore-forming Gram-positive, facultative, and thermophilic anaerobes. They are organisms that have the potential to produce chemicals and to be used for bioremediation $[19,20]$. Naturally, representatives of Geobacillus species are isolated in different environments such as volcanic springs, hydrothermal openings, oil wells, and piles of compost. This group of organisms exhibit growth over a great range of temperatures and have the ability to grow well between 40 to $70{ }^{\circ} \mathrm{C}$ and optimally at 55 to $65^{\circ} \mathrm{C}$ [21]; these are abnormal temperatures for most bacteria. Due to this capacity, researchers believe that the enzymes produced by the cells are also thermostable. Since Geobacillus species grow at much higher temperatures than Bacillus, it is expected that the protease from the Geobacillus genus will share some similar overall structures and functions to those from $B$. subtilis, though with higher stability and activity at higher temperatures.

The growth and protease production by microorganisms are greatly affected by the cultural conditions $[16,22]$. Hence, by manipulating the cultural conditions, the productivity of yield can be increased. Moreover, the optimization process can be also used to explore the ability of microorganisms 
to withstand the harsh and drastic environmental changes, which will be beneficial for production process strategies. Therefore, parameters including carbon and nitrogen sources, temperature, $\mathrm{pH}$, time of incubation, $\mathrm{NaCl}$ concentration, and inoculum sized are often optimized to get a maximum yield of protease enzyme [16,22,23]. This present study screened, isolated, and identified a thermophilic Geobacillus species from Sungai Klah Hot Spring Park, Perak, Malaysia focusing on the growth dynamic of the G. thermoglucosidasius SKF4 and its ability to produce a thermostable protease enzyme under different cultural conditions.

\section{Materials and Methods}

\subsection{Sample Collection}

The hot spring water and soil sediments were collected from Sungai Klah Hot Spring Park located in Perak, Malaysia (035' $40 \mathrm{~N}$ and $101^{\circ} 23^{\prime} 33 \mathrm{E}$ ) (Figure 1). According to Chan et al. [24], Sungai Klah (SK) is described as a shallow and fast-flowing stream hot spring with $150 \mathrm{~m}$ in length and reputed to be the second hottest hot spring in Malaysia with temperatures from 50 to $110^{\circ} \mathrm{C}$ and $\mathrm{pH}$ of 7.0 to 9.0 . Its level of total organic content (TOC) is very high relatively, due to its location in an obscure forested area and the hot spring being frequently fed by plant litter. The temperature and $\mathrm{pH}$ of Sungai Klah hot spring were measured in situ ( 89.0 to $90.5^{\circ} \mathrm{C}$ and $\mathrm{pH} 8.6$ to 8.7 with dissolved oxygen at $28.1 \%$ ). The water samples were stored in a thermos and the soil sediments were placed in a sterilized bottle and then conveyed to the laboratory in less than $6 \mathrm{~h}$.

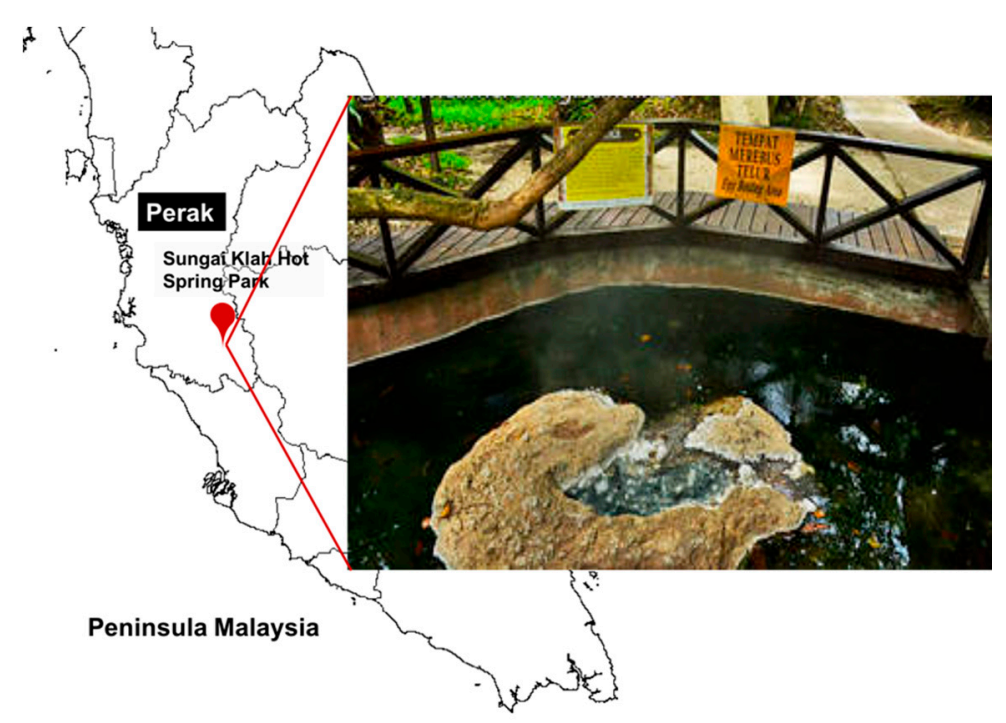

Figure 1. Sungai Klah Hot Spring Park located in Perak, Malaysia.

\subsection{Qualitative Screening of Protease Activity}

The proteolytic activity of thermophilic bacteria was screened on skim milk agar (SMA). Briefly, $1 \mathrm{~g}$ of soil sample was added to a glass tube containing $10 \mathrm{~mL}$ sterilized distilled water. The soil suspension in the test tube was heated in a water bath at $80^{\circ} \mathrm{C}$ for $15 \mathrm{~min}$ and instantly cooled in water mixed with ice. Then, $100 \mu \mathrm{L}$ of samples were spread on SMA agar plates (1\% Bactotryptone, $0.5 \% \mathrm{NaCl}, 0.5 \%$ Yeast Extract and $1 \%$ Skim milk) and then incubated at $60{ }^{\circ} \mathrm{C}$ for $36 \mathrm{~h}$. Colonies that produced clear zone as a result of partial hydrolysis of casein in the milk were carefully picked and re-streaked on Luria Bertani (LB) agar plate to obtain a pure culture. Additionally, the selected isolates were streaked on LB agar slants and stored in the chiller at $4{ }^{\circ} \mathrm{C}$. 


\subsection{Protease Activity Assay}

Enzyme activity was measured according to the method described by McDonald and Chen [25]. Three replicates of tubes were used for the assay; in these tubes, $2 \mathrm{~mL}$ of $1 \%(w / v)$ casein in Glycine-NaOH buffer with $\mathrm{pH} 10$ was added in all three test tubes. The control contained $2 \mathrm{~mL}$ of $1 \%(w / v)$ casein solution, $1 \mathrm{~mL}$ of enzyme, and $3 \mathrm{~mL} \mathrm{10 \%} \mathrm{TCA}(w / v)$. The rest of the two tubes containing $2 \mathrm{~mL}$ of $1 \%$ $(w / v)$ casein solution and $1 \mathrm{~mL}$ of enzyme then were incubated at $60^{\circ} \mathrm{C}$ for $15 \mathrm{~min}$. After the incubation, $3 \mathrm{~mL}$ of $10 \%$ TCA was added and then centrifuged for three minutes. One millileter of supernatant in the test tube was added to $5 \mathrm{~mL}$ of alkaline copper reagent. After $15 \mathrm{~min}, 0.5 \mathrm{~mL}$ of Folin-Cocteau reagent was diluted in a 1:1 ratio and put to stand for $30 \mathrm{~min}$. After that, the absorbance was read spectrophotometrically at $700 \mathrm{~nm}$. One unit of enzyme activity is defined as the amount of enzyme that releases $1 \mu \mathrm{g}$ of tyrosine per $\mathrm{mL}$ per min under the above assay conditions.

\subsection{Morphology of the Colonies}

Briefly, the isolates were grown on LB agar for $48 \mathrm{~h}$ and then the colony morphologies were observed with regard to color, shape, margin, internal structure, and elevation. Further, Gram staining was performed to evaluate the Gram characteristics and the cell morphologies of the isolates.

\subsection{Molecular Identification of Isolate SKF4}

The selected isolate was grown in LB broth at $60{ }^{\circ} \mathrm{C}$ overnight. After the incubation time, the cultures were centrifuged at 23,000 $\mathrm{g}$ for $5 \mathrm{~min}$ and the cell pellets were collected and used for DNA extraction using QIAamp DNA Mini Kit (Qiagen GmbH, Hilden, Germany) according to the manufacturer's instructions. Further, the genomic DNA was amplified using universal primer 1492R (5'TACGGYTACCTTGTTACGACTT3') and primer 27F (5'AGAGTTTGATCMTGGCTCAG3'). The PCR product was purified using the QIAquick PCR Purification Kit (Qiagen, Germany) and sent for sequencing at First BASE Asia Sdn. Bhd. (Selangor, Malaysia). The sequence obtained was then compared using The NCBI Basic Local Alignment Search Tools (BLAST; http://www.ncbi.nlm.nih.gov/) to search for a similar sequence with a collection of $16 \mathrm{~S}$ rRNA sequences in the GenBank. Bacterial identifications were performed primarily based on the comparison between the physiological and microscopic characteristics outlined in Bergey's Manual and compilation data of biochemical and morphological characteristics done on the isolates [26]. The sequences and their closest relative were retrieved and aligned with ClustalW, whereas phylogenetic tree analysis was achieved using a neighbor-joining technique by Mega software version 7.0 (The Biodesign Institute, Tempe, AZ, USA). Evolutionary distances of nucleotide sequences were computed using the Jukes-Cantor model (bootstrap values: 1000 resampling) [27].

\subsection{Effects of Cultural Conditions on Bacterial Growth and Protease Production of Isolate SKF4}

The influences of various factors on the growth and protease production of the G. thermoglucosidasius SKF4 were studied. Parameters such as temperature, $\mathrm{pH}$, amount of sodium chloride, carbon and nitrogen supplies, and period of incubation of the bacterium were assessed following the method of Sepahy and Jabalameli [23] with some modifications. The bacterial growth was determined by measuring optical density (OD) using a spectrophotometer at $600 \mathrm{~nm}$ [23]. Inoculum for protease production from $G$. thermoglucosidasius SKF4 was carried out using a modified method of Sinha and Khare [28] at $\mathrm{pH} 7$ in a medium that contained $5 \mathrm{~g}$ bactopeptone; $5 \mathrm{~g}$ yeast extract; $3 \mathrm{~g} \mathrm{NaCl}$; and $0.2 \mathrm{CaCl}$, $5 \mathrm{~g} \mathrm{KH}_{2} \mathrm{PO}_{4}$, and $0.1 \mathrm{~g} \mathrm{FeSO}_{4} \cdot 7 \mathrm{H}_{2} \mathrm{O}$ dissolved in litre of distilled water. Inoculums were regularly grown in LB broth medium. Overnight cultures were centrifuged at $23,000 \times g$ for $15 \mathrm{~min}$ at $4{ }^{\circ} \mathrm{C}$ and the supernatant was used for protease production assay following the procedure described earlier [25]. The experiment was performed in triplicate. This method was applied to all the following parameters: 


\subsubsection{Effects of Temperature}

Briefly, about 5\% inoculum of isolate SKF4 was inoculated in sterilized LB broth followed by incubation at various temperatures $\left(40,45,50,55,60,65,70\right.$, and $\left.75^{\circ} \mathrm{C}\right)$ for $24 \mathrm{~h}$ with $200 \mathrm{rpm}$ agitation.

\subsubsection{Effects of Carbon Sources}

For the effects of carbon sources, the medium was prepared at $\mathrm{pH} 7$ in flasks containing $1 \%(w / v)$ of selected carbon sources. The carbon sources used were glucose, fructose, maltose, xylose, sucrose, and lactose. The carbon source media were autoclaved at $121^{\circ} \mathrm{C}$ for $15 \mathrm{~min}$ and cooled down prior to inoculation with $5 \%(v / v) \mathrm{G}$. thermoglucosidasius SKF4 and incubated at $60{ }^{\circ} \mathrm{C}$ for $24 \mathrm{~h}$ with $200 \mathrm{rpm}$ of agitation.

\subsubsection{Effects of $\mathrm{pH}$}

Briefly, $5 \%(v / v)$ inoculums of isolate SKF4 was inoculated in a sterilized broth medium set at various $\mathrm{pH}$ values ( $\mathrm{pH} 5,6,7,8$, and 9) and incubated at $60^{\circ} \mathrm{C}$ for $24 \mathrm{~h}$ with $200 \mathrm{rpm}$ of agitation.

\subsubsection{Effects of Nitrogen Sources}

The growth media were prepared containing $1 \%(w / v)$ of one of the following nitrogen sources: sodium nitrate, urea, casein, ammonium sulfate, or yeast. The media were set at $\mathrm{pH} 7$ and sterilized by autoclaving prior to inoculation with $5 \%(v / v)$ of isolate SKF4.

\subsubsection{Effects of Incubation Time}

An optimized production sterilized medium was prepared in a $50 \mathrm{~mL}$ conical flask and inoculated with $5 \%(v / v)$ culture of isolate SKF4. The culture media were incubated at $60{ }^{\circ} \mathrm{C}$ with $200 \mathrm{rpm}$ agitation. At every $6 \mathrm{~h}$ interval, samples were taken and the growth and protease production were determined accordingly.

\section{Results and Discussion}

\subsection{Isolation and Identification of Isolate SKF4}

Investigations of hot spring microbial populations can provide an amazing and unlimited supply of new microorganisms that may perhaps display an important variation from known terrestrial phylotypes. From these organisms, we can obtain a series of enzymes and other products, which might offer a very important resource for the advancement of biotechnology. In the present study, a total number of 14 isolates belonging to a different group of bacteria were successfully isolated from the Sungai Klah Hot Spring Park located in Perak, Malaysia (Figure 1). The temperature of the Sungai Klah hot spring water was in the range of 60 to $90{ }^{\circ} \mathrm{C}$, while the $\mathrm{pH}$ recorded was in the range of 8.6 to 8.7. All the isolates were observed to hydrolyze skim milk agar with the production of a clear zone around the colonies. Further, the isolates were screened both quantitatively and qualitatively for protease enzyme production (Table 1), resulting in one isolate that exhibited a promising protease production potential (175 U/mL); namely, isolate SKF4 (Figure 2B), which we selected for identification and subsequent studies. Our finding is in agreement with that by Brumm et al. [12], who reported that Geobacillus species could be isolated from alkaline or neutral hot springs with temperatures between 60 and $80{ }^{\circ} \mathrm{C}$, which is an important natural environment for the growth of genus Geobacillus.

Based on the presence of certain physiological and phenotypical properties, such as endospore formation and its ability to grow and produce enzyme optimally at elevated temperatures, isolate SKF4 was preliminarily identified as Geobacillus. Morphologically, the isolate SKF4 produced large colonies with circular borders, convex in elevation with an entire margin, and identified as opaque with respect to opacity (Figure 2A). Moreover, SKF4 was found to be a Gram-positive rod-shaped bacterium. 
The morphological and physiological characterization and identification of SKF4 that belonged to the genus Geobacillus agree with the conclusions of earlier reports [29-31].

Table 1. Protease activity and zone of inhibition of isolates from Sungai Klah hot spring.

\begin{tabular}{ccc}
\hline Isolate & Zone of Hydrolytic Halo $(\mathbf{c m})$ & Activity $(\mathbf{U} / \mathbf{m L})$ \\
\hline F1 & 3.0 & 148 \\
F2 & 3.0 & 160 \\
F3 & 3.5 & 150 \\
F4 ${ }^{\text {a }}$ & 3.5 & 175 \\
C1 & 3.0 & 145 \\
C2 & 3.3 & 145 \\
C3 & 3.1 & 140 \\
C4 & 3.0 & 141 \\
C5 & 3.2 & 100 \\
C6 & 2.0 & 80 \\
D2 & 2.8 & 75 \\
L8 & 3.0 & 81 \\
\hline
\end{tabular}

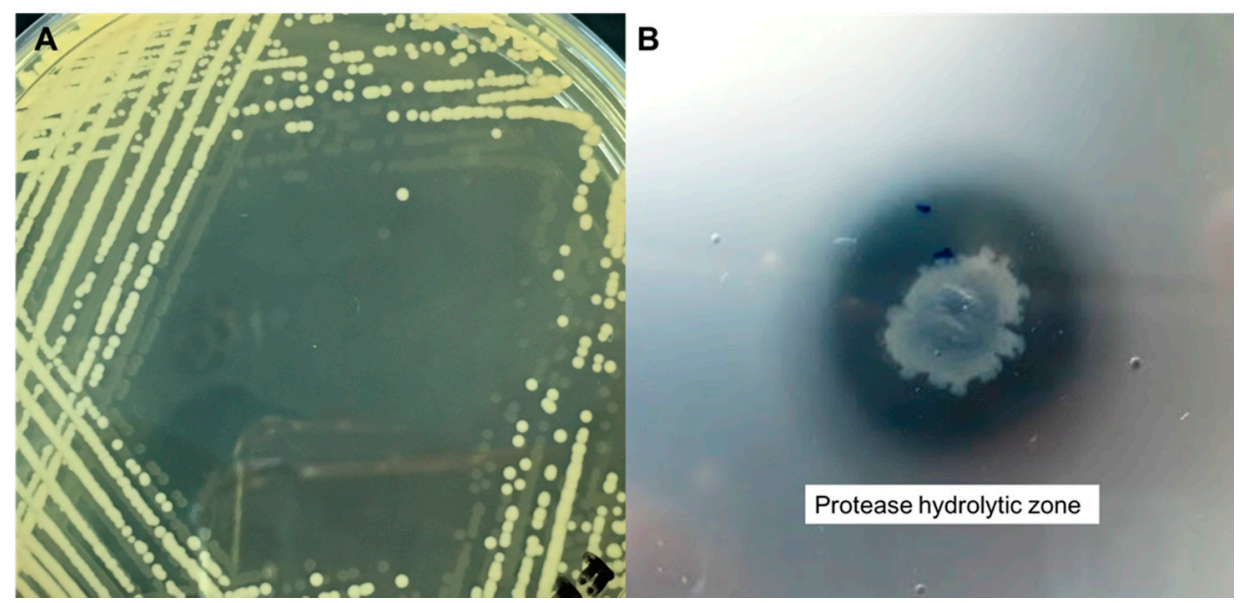

Figure 2. (A) Growth and colony morphology of isolate SKF4 on Luria Bertani agar. (B) Protease activity of isolate SKF4 on skim milk agar.

In this study, the amplified 16S rRNA gave an intact band of $1500 \mathrm{bp}$ DNA fragment (Figure 3A). Further, the 16S rRNA gene analysis of isolate SKF4 revealed the highest (98\% to 99\%) sequence similarities with genus Geobacillus and was concluded to belong to Geobacillus species. Based on the phylogenetic relationship analysis using the neighbor-joining method (Figure 3B), isolate SKF4 has a very strong relationship with strain $G$. thermoglucosidasius NP-1 with $99.87 \%$ similarity. These results are in agreement with the report of Nazina et al. [8], which stated that there is more than $96 \%$ sequence homology among the members of Geobacillus species. Thus, the isolate SKF4 can be allocated into G. thermoglucosidasius considering that it has $99 \%$ similarity with the species of G. thermoglucosidasius and tentatively identified as G. thermoglucosidasius SKF4. The nucleotide sequence of the 16S rRNA gene of G. thermoglucosidasius SKF4 was deposited to GenBank under the accession number of MN960021.

A few chemicals and enzymes have been produced from G. thermoglucosidasius, mostly ethanol; however, little information about the production of serine proteases has been found. G. thermoglucosidasius species have been observed to be sources of many enzymes, including an alcohol dehydrogenase (ADH) enzyme for isobutanol production [20] and acrylamidase [32]. Cha and Chambliss [32] reported the cloning of the acrylamide gene from G. thermoglucosidasius AUT-01, a nitroalkane-oxidizing enzyme, and the cloning of the gene [33]. Additionally, a novel $\beta$-xylosidase enzyme that belongs to CAZy glycoside hydrolase family GH52 has been cloned and expressed in Escherichia coli [34]. Moreover, 
Szeker et al. [35] described the cloning and expression of two thermostable pyrimidine nucleoside phosphorylases (PyNP) isolated from G. thermoglucosidasius and Thermus thermophilus. Further, a Laccase gene from G. thermoglucosidasius 95A1 was successfully cloned and expressed in E. coli DH5 $\alpha$ [36]. To our knowledge, no study reported the production of thermostable alkaline protease by G. thermoglucosidasius. Therefore, our isolate, strain SKF4 will be the first report of the production of the protease enzyme by G. thermoglucosidasius sp.

A

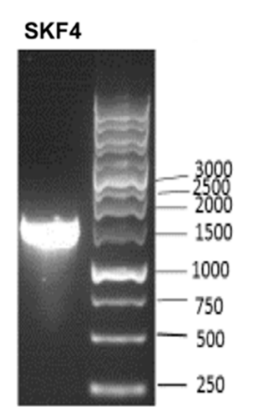

B

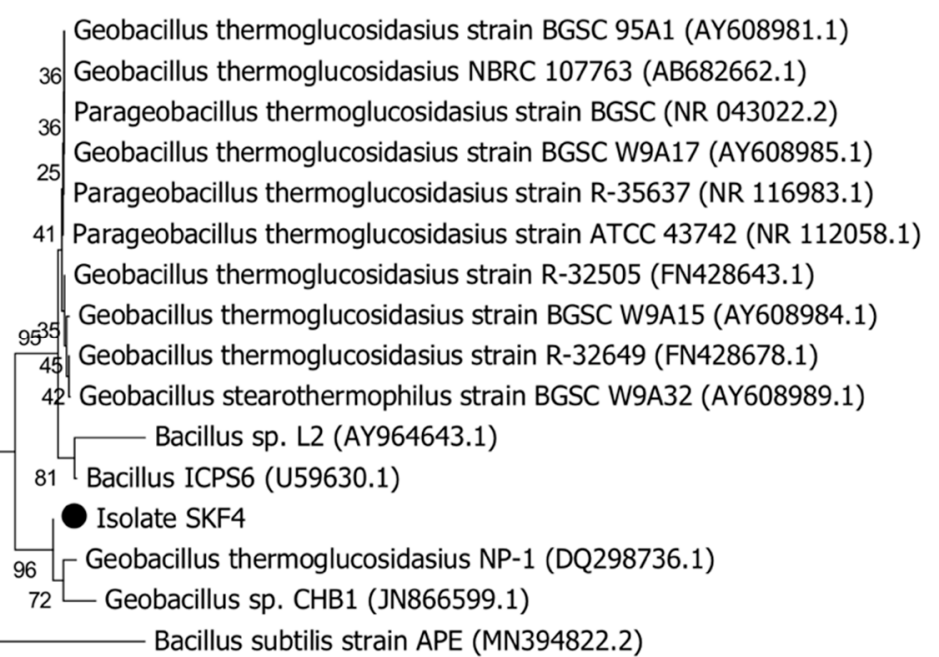

0.01

Figure 3. (A) The agarose gel electrophoresis of $16 \mathrm{~S}$ rRNA amplified from the genomic DNA of the isolate SKF4 using 27F and 1492R primers. (B) Phylogenetic tree of Geobacillus thermoglucosidasius SKF4. The tree is drawn to scale, with branch lengths in the same units as those of the evolutionary distances used to infer the phylogenetic tree. The analysis involved 15 nucleotide sequences of some closely related species. Bacillus subtillis was placed as an outer group.

Furthermore, a more precise classification should be considered in the future, which will provide additional characteristics, such as DNA-DNA hybridization data. Information regarding the use of Geobacillus sp. to produce enzymes is rare, especially protease enzymes. However, there is no published work on the evaluation of the dynamic growth and protease enzyme production by G. thermoglucosidasius. To our knowledge, this is the first study on G. thermoglucosidasius ever conducted.

\subsection{Effects of Different Parameters on the Growth and Protease Production of G. thermoglucosidasius SKF4}

\subsubsection{Effects of Temperature}

Temperature has been identified as among the essential factors influencing bacteria growth and their ability to produce protease enzymes. Consequently, isolate SKF4 was grown at different temperatures $\left(40,50,55,60,65,70\right.$, and $\left.75^{\circ} \mathrm{C}\right)$. In this study, isolate SKF4 showed optimum growth at a temperature between 55 and $65^{\circ} \mathrm{C}$ and maximum growth at $60^{\circ} \mathrm{C}$. Further, the production of protease enzyme occurred between the temperatures of 55 and $65^{\circ} \mathrm{C}$ with maximal activity of 182 and $171 \mathrm{U} / \mathrm{mL}$ at 60 and $65^{\circ} \mathrm{C}$, respectively (Figure $4 \mathrm{~A}$ ). In previous studies, the growth and production of protease by Geobacillus species have been reported to fall between 55 to $70{ }^{\circ} \mathrm{C}$. Dissanayaka and Rathnayake [37] reported the optimum growth of some Geobacillus sp. between 30 and $70{ }^{\circ} \mathrm{C}$ with maximum activity at $60^{\circ} \mathrm{C}$. Similarly, other reports showed the growth of thermophilic Geobacillus isolate producing protease enzyme at optimum temperatures ranging from 60 to $62{ }^{\circ} \mathrm{C}$ [13]. Additionally, Chen et al. [38] reported a thermophile G. caldoproteolyticus isolated from sewage with the capacity to grow at 35 to $65{ }^{\circ} \mathrm{C}$. Moreover, reports by Nielsen and Villadsen, [39] and Bhunia et al. [38] stated that temperature affects the 
specific growth rate of bacteria; there was a gradual increase in specific growth rate until the optimum temperature and then a rapid decrease beyond the optimum temperature. However, this observation was species-dependent, as it has been reported by Shanthakumari and Boominathan [40] that there is a great variation among the optimum temperatures required for different species for protease production.

A

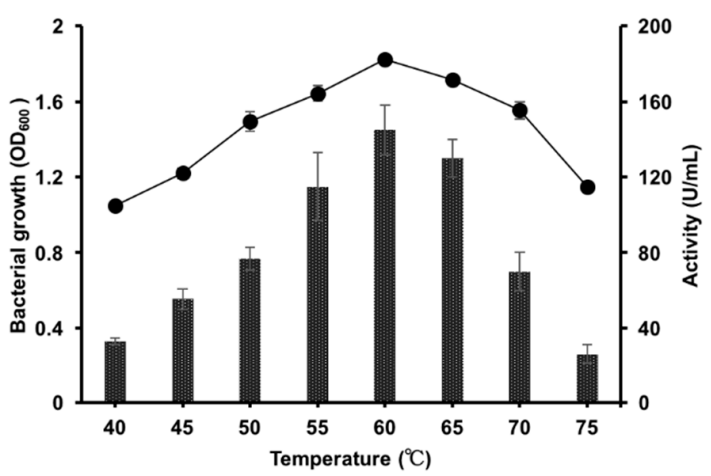

C

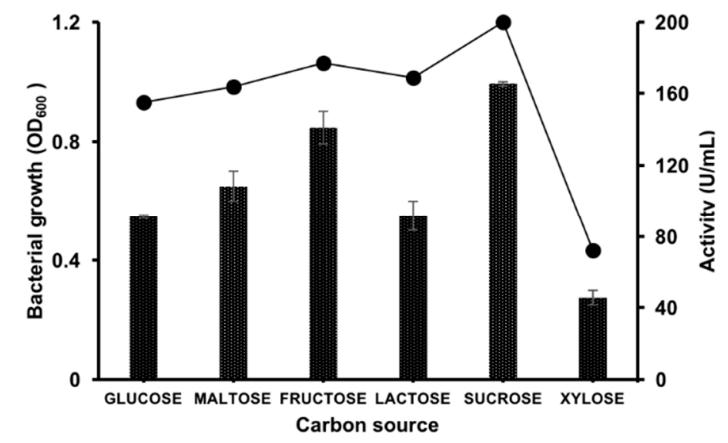

E

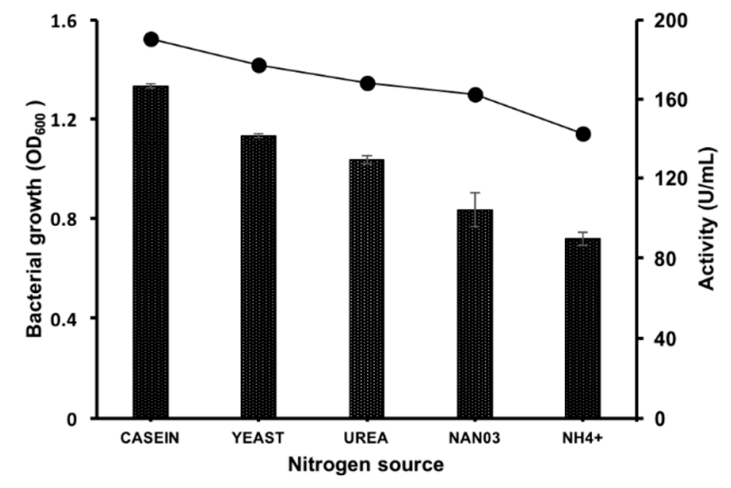

B

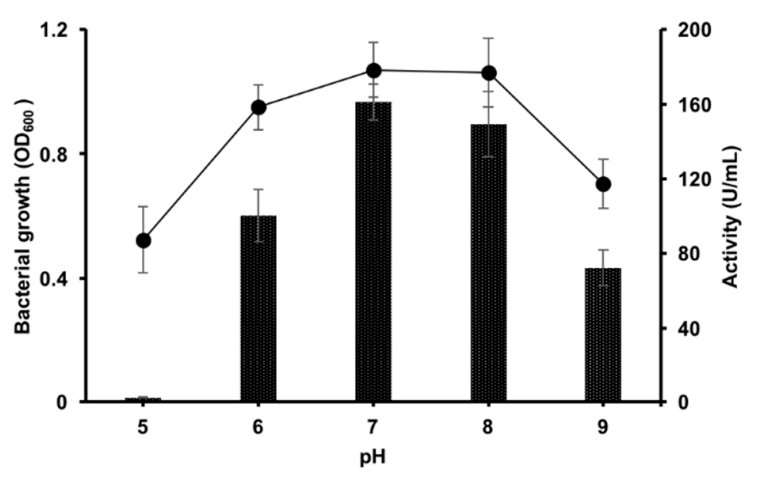

D

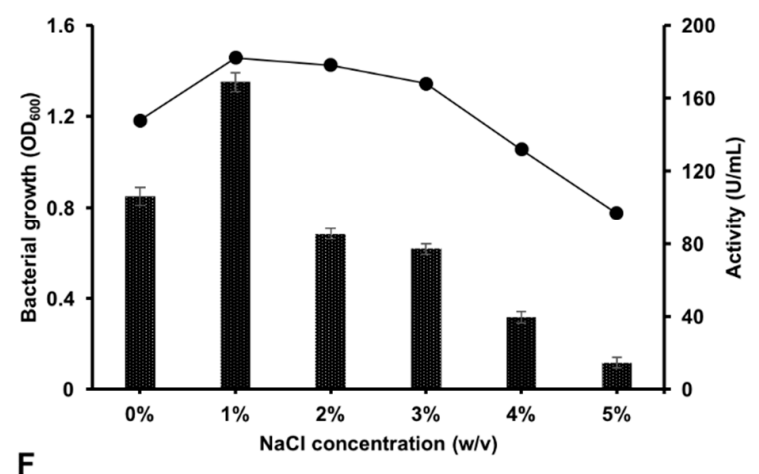

F

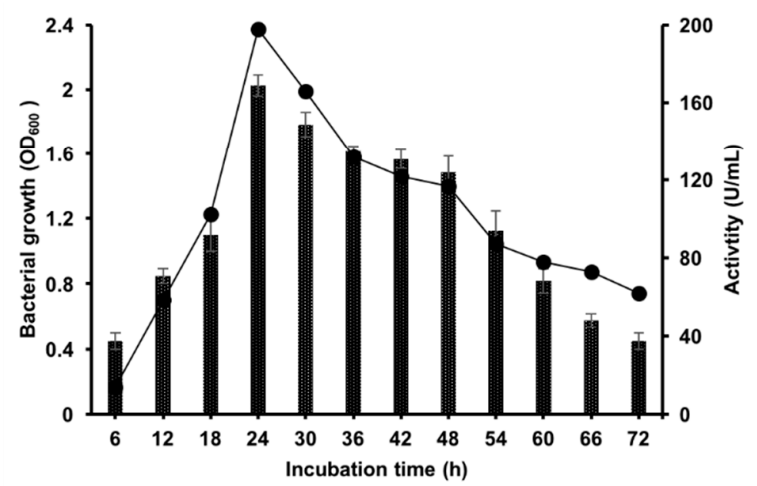

OD $\rightarrow$-Activity

Figure 4. Effects of (A) temperature, (B) $\mathrm{pH},(\mathbf{C})$ carbon source, (D) $\mathrm{NaCl}$ concentration, (E) nitrogen source, and (F) incubation time on growth and protease production of $G$. thermoglucosidasius SKF4. Data are expressed as means $(n=3) \pm$ SDs.

The ability of thermophilic bacteria to withstand high temperatures could be explained by the activity in their metabolic functions associated with their physiological adaptations. There are two ways in which the effects of temperatures on the organism can be explained. When temperature increases, chemical reactions and enzymatic reactions proceed faster and the growth rate also increases. Additionally, when the temperature increases, proteins become irreversibly damaged. Besides, thermophiles are much more stable to heat through molecular adaptation due to their intracellular enzymes, and other factors, such as salts, high protein concentration, coenzymes, substrates, activators, 
and general stabilizers [41]. Chakravorty and Petra [42] and Margaryan et al. [43] suggested that the most important mechanistic determining factors of thermoadaptation in Bacilli are the adaptation of composition regarding the membrane lipids, heat shock membrane synthesis (HSPs), and the ability of the enzyme to adapt to produce molecular stability and structural flexibility. Furthermore, thermoadaptation of the thermophiles was also due to the GC content in their genome, which was observed to be very high. In this study, isolate SKF4 demonstrated maximal protease activity at a high temperature, which is acceptable for industrial characteristics.

\subsubsection{Effects of $\mathrm{pH}$}

The changes in $\mathrm{pH}$ noticeably affected the growth and activity of the bacteria isolate SKF4. It was observed that the variation in the $\mathrm{pH}$ played a key role in the growth and protease activity of the bacteria. Highest growth and protease production were observed at $\mathrm{pH} 7$ and 8 (Figure 4B). Similarly, Sepahy and Jabalameli [23] reported the maximum growth and protease production by Bacillus sp. at $\mathrm{pH} 8$, which is in agreement with our finding on the relationship between the growth of bacteria and their production of protease enzyme. Most of the Geobacillus sp. reported have their growth at a $\mathrm{pH}$ range of 6-9 for the production of protease [38,44].

For the ability of an organism to produce protease extracellularly, the $\mathrm{pH}$ of the environment or culture medium is a very important condition to consider; this is due to the binding of substrate to the catalyst, and a catalytic reaction usually takes place depending on the charge distribution of substrates and enzyme molecules [45]. Additionally, the metabolic pathways of microorganisms are affected by $\mathrm{pH}$. When there is an adjustment in the $\mathrm{pH}$ of the external medium, there is also a change in the ionization of the nutrient molecules, which consequently reduces the nutrients available to the bacteria and hence reduces the overall metabolic activity [45]. The $\mathrm{pH}$ of a medium influences the transportation of various constituents across the membrane. The effects of $\mathrm{pH}$ on bacterial metabolism in culture media, including broth, on a molecular basis are still hard to understand. The $\mathrm{pH}$ of a medium influences the motive force of the proton in chemiosmosis; therefore, there is a possibility that the relative efficiency of its metabolic activities is attained maximum under the optimum $\mathrm{pH}$ range [46].

\subsubsection{Effects of the Carbon Source}

The influences of various carbon sources on cell growth and protease production were studied using glucose, maltose, fructose, lactose, xylose, and sucrose. In this study, isolate SKF4 showed good growth for most of the carbon sources used with the exception of xylose. Among the carbon sources, sucrose has the highest protease activity with $200 \mathrm{U} / \mathrm{mL}$, followed by fructose with $177 \mathrm{U} / \mathrm{mL}$. However, lower activity was recorded in glucose and xylose, 155 and $72 \mathrm{U} / \mathrm{mL}$, respectively (Figure 4C).

The capability of an organism to break down different carbohydrates could be a result of the preference of the microorganism towards living in an environment that is low in organic content, and therefore the need to develop its systems to adjust to absorption of any food available in such environments [47]. Glucose is regularly used as a carbon source to produce protease enzymes through fermentation. Reports from different investigations showed that the production of protease enzyme was reduced by glucose due to glucose catabolic repression [48-50].

Moreover, other carbohydrates have been reported by many investigators to cause an increase in the yield of alkaline protease. For example, Malathi and Chakraborty [51] stated in their work that maltose is a good source of carbon for the high production of protease enzyme. Tsuchiya et al. [52] also reported the use of maltose for high production of protease enzyme, while Phadatare et al. [53] and Ibrahim et al. [1] reported on high protease enzyme activity using sucrose and fructose respectively. Further, Yang et al. [54] published that G. thermodenitrificans SG-01 utilizes fructose to grow, while G. thermodenitrifcans SG-02 utilizes fructose and glucose for maximum growth and G. denitrificans SG-03 utilizes sucrose. 


\subsubsection{Effects of $\mathrm{NaCl}$ Concentration}

The results presented in Figure 4D show that the isolate SKF4 was capable of growing over a wide range of $\mathrm{NaCl}$ concentrations from $0 \%$ to $5 \%$ with optimum growth and protease production activity $(182 \mathrm{U} / \mathrm{mL})$ at a concentration of $1 \%$ with appreciable activity at $2 \%$ and $3 \%$ concentrations. However, the growth of isolate SKF4 and its protease production drastically dropped when grown at $4 \%$ and $5 \% \mathrm{NaCl}$ concentrations (Figure 4D). Similarly, Zahoor et al. [15] reported the growth of isolate Geobacillus TP-5 in the range of $0 \%$ to $3.5 \% \mathrm{NaCl}$ concentration with an optimum at $0.5 \%$. Our findings are also in line with the work of Yang et al. [54] who reported the growth of Geobacillus sp. SG01 at NaCl concentrations of $0 \%$ to $2 \%$ with optimum growth at a $1 \%$ concentration of salt. Likewise, Geobacillus sp. from other studies has been also reported having the ability to grow within the range of $\mathrm{NaCl}$ concentration $0 \%$ to $5 \%$ [29,55]. Contradictorily, Kalwasinska et al. [56] reported an increase in protease production as the $\mathrm{NaCl}$ concentration increased $(1 \%$ to $9 \% \mathrm{NaCl})$ with maximum production at $4-5 \%$ $\mathrm{NaCl}$ concentration for $\mathrm{B}$. luteus $\mathrm{H} 11$. The strain $\mathrm{H} 11$ was isolated from a highly saline soda-lime pond, and proved to be highly tolerant to salinity [56]. In this study, isolate SKF4 was isolated from a hot spring with low level of salt concentration, which might be the reason why the isolate SKF4 has optimum production at a $1 \% w / v \mathrm{NaCl}$ concentration. Moderately Gram-positive halophiles usually reduce enzyme production at a high salt concentration [56,57]. Our isolate can also be considered to be moderately halotolerant.

\subsubsection{Effects of Nitrogen Sources}

Various nitrogen sources were investigated for the growth and protease production of isolate SKF4. Results obtained (Figure 4E) revealed that the use of casein as a nitrogen source demonstrated maximum growth and protease production $(190 \mathrm{U} / \mathrm{mL})$ of isolate SKF4, followed by yeast extract. Different organisms require different specific nitrogen supplements for growth and metabolism. Our result is in line with Khusro et al. [45], who reported that the production of protease by bacteria increased when supplemented with $1 \%(w / v)$ of casein. Sharma et al. [58] stated that different organic nitrogen sources, either complex or simple; inorganic sources; and amino acids, have been used as good sources of nitrogen among researchers to improve the production of protease enzyme. Nitrogen sources like yeast extract have been discovered to be good sources for maximum production of protease due to various amino acids, vitamins, and carbohydrates that are enough to support growth and enhance the metabolic functions of the bacteria [59]. This is in agreement with the findings of Khusro [45], who reported that yeast extract played a crucial role in the production of the enzyme due to the presence of important elements and growth factors for microorganisms [45]. Prakasham et al. [60] reported the use of a complex organic nitrogen compound resulting in an increase of protease amount secreted compared to that when using an inorganic nitrogen compound. Similarly, Qureshi et al. [61] reported an increase in the amount of protease produced by B. subtilis EFRL 01 when using organic nitrogen sources from yeast extract.

\subsubsection{Effects of Incubation Time}

In this study, the effects of incubation time (6 to $72 \mathrm{~h}$ ) on growth and protease production of isolate SKF4 were examined. The results obtained showed that the best growth for isolate SKF4 was between 24 and $48 \mathrm{~h}$ with the highest growth observed at $24 \mathrm{~h}$. Additionally, protease production was seen to be optimal at 24 and $30 \mathrm{~h}$ with 200 and $165 \mathrm{U} / \mathrm{mL}$ activity, respectively, and rapidly decreased in activity by up to $72 \mathrm{~h}$ at a constant rate (Figure $4 \mathrm{~F}$ ). The production of protease was observed to be proportional to the growth of the organism. This is in agreement with Thebti et al. [44], who stated that the production of protease enzyme is proportional to the bacterial growth, and that maximum growth and protease production of G. toebii strain LBT 77 were observed at $42 \mathrm{~h}$ of incubation, which also coincides with the end of stationary phase with maximum protease production of $1900 \mathrm{U} / \mathrm{mL}$. The production of protease and maximum growth of isolate SKF4 after $24 \mathrm{~h}$ of incubation might be 
a result of the increased growth rate of the organism due to the high rate of metabolism, allowing it to reach the stationary phase at a shorter time of incubation. The finding is also in accordance with that by Chen et al. [38], who observed protease maximum production in G. caldoproteolyticus at late stationary growth phase with maximum protease activity after $9 \mathrm{~h}$ of incubation.

\section{Conclusions}

A number of protease-producing bacterial strains have been screened and isolated from water and soil sediment of Sungai Klah Hot Spring Park, Malaysia. The isolate that demonstrated the highest clear zone on skim milk agar and the highest activity of protease production was selected for identification and further investigation. Based on the 16S rRNA gene analysis, SKF4 was identified as G. thermoglucosidasius. The study on the effects of various parameters had showed the organism's highest ability to produce protease enzyme and optimum growth at the high temperature of 60 and $65^{\circ} \mathrm{C}$ with a $\mathrm{pH}$ of 7 and 8 . This indicates that the organism has the capacity to produce thermostable protease. This study has also revealed that the G. thermoglucosidasius SKF4 was able to utilize various sugar and nitrogen sources for growth and protease production, besides showing a maximum capacity to utilize casein and yeast as sources of nitrogen and sucrose and fructose as good sources of carbon. A new alternative source of protease for commercial production of thermostable protease is required to find a better alternative for commercial use [23]. Thus, it can be stated that G. thermoglucosidasius SKF4 has a promising potential to be used as thermostable protease producer for commercial use in the industry with regards to its high activity at high temperature and high $\mathrm{pH}$ with moderate salinity. The gene encoding the thermostable protease could be cloned into a mesophilic organism like E. coli.

Author Contributions: Conceptualization, A.D.S. and N.A.R.; data curation, A.D.S., N.A.R., H.M.Y., F.M.S., and N.A.Y.; formal analysis, A.D.S. and N.A.R.; funding acquisition, N.A.R.; investigation, A.D.S.; methodology, A.D.S. and N.A.R.; project administration, N.A.R.; resources, N.A.R.; software, H.M.Y.; supervision, N.A.R., F.M.S., and N.A.Y.; validation, N.A.R., H.M.Y., F.M.S., and N.A.Y.; visualization, A.D.S. and H.M.Y.; writing-original draft, A.D.S.; writing-review and editing, N.A.R., H.M.Y., F.M.S., and N.A.Y. All authors have read and agreed to the published version of the manuscript.

Funding: This research received no external funding.

Acknowledgments: The authors would like to thank Universiti Putra Malaysia for the financial support given.

Conflicts of Interest: The authors declare no conflict of interest.

\section{References}

1. Ibrahim, A.S.S.; Al-Salamah, A.A.; Elbadawi, Y.B.; El-Tayeb, M.A.; Ibrahim, S.S.S. Production of extracellular alkaline protease by new halotolerant alkaliphilic Bacillus sp. NPST-AK15 isolated from hyper saline soda lakes. Electron. J. Biotechnol. 2015, 18, 236-243. [CrossRef]

2. Yildirim, V.; Baltaci, M.O.; Ozgencli, I.; Sisecioglu, M.; Adiguzel, A.; Adiguzel, G. Purification and biochemical characterization of a novel thermostable serine alkaline protease from Aeribacillus pallidus C10: A potential additive for detergents. J. Enzym. Inhib. Med. Chem. 2017, 32, 468-477. [CrossRef] [PubMed]

3. Rao, M.B.; Tanksale, A.M.; Ghatge, M.S.; Deshpande, V.V. Molecular and biotechnological aspects of microbial proteases. Microbiol. Mol. Biol. Rev. 1998, 62, 597-635. [CrossRef] [PubMed]

4. Mahajan, R.T.; Badgujar, S.B. Biological aspects of proteolytic enzymes: A Review. J. Pharm. Res. 2010.

5. Subba Rao, C.; Sathish, T.; Ravichandra, P.; Prakasham, R.S. Characterization of thermo- and detergent stable serine protease from isolated Bacillus circulans and evaluation of eco-friendly applications. Process Biochem. 2009, 44, 262-268. [CrossRef]

6. Baker, G. Bacterial community analysis of Indonesian hot springs. FEMS Microbiol. Lett. 2001, 200, 103-109. [CrossRef]

7. Bertoldo, C.; Antranikian, G. Starch-hydrolyzing enzymes from thermophilic archaea and bacteria. Curr. Opin. Chem. Biol. 2002, 6, 151-160. [CrossRef] 
8. Nazina, T.N.; Tourova, T.P.; Poltaraus, A.B.; Novikova, E.V.; Grigoryan, A.A.; Ivanova, A.E.; Lysenko, A.M.; Petrunyaka, V.V.; Osipov, G.A.; Belyaev, S.S.; et al. Taxonomic study of aerobic thermophilic bacilli: Descriptions of Geobacillus subterraneus gen. nov., sp. nov. and Geobacillus uzenensis sp. nov. from petroleum reservoirs and transfer of Bacillus stearothermophilus, Bacillus thermocatenulatus, Bacillus th. Int. J. Syst. Evol. Microbiol. 2001. [CrossRef]

9. Meintanis, C.; Chalkou, K.I.; Kormas, K.A.; Karagouni, A.D. Biodegradation of Crude Oil by Thermophilic Bacteria Isolated from a Volcano Island. Biodegradation 2006, 17, 3-9. [CrossRef]

10. Lama, L.; Calandrelli, V.; Gambacorta, A.; Nicolaus, B. Purification and characterization of thermostable xylanase and $\beta$-xylosidase by the thermophilic bacterium Bacillus thermantarcticus. Res. Microbiol. 2004, 155, 283-289. [CrossRef]

11. Schallmey, M.; Singh, A.; Ward, O.P. Developments in the use of Bacillus species for industrial production. Can. J. Microbiol. 2004, 50, 1-17. [CrossRef] [PubMed]

12. Brumm, P.J.; Land, M.L.; Mead, D.A. Complete genome sequence of Geobacillus thermoglucosidasius C56-YS93, a novel biomass degrader isolated from obsidian hot spring in Yellowstone National Park. Stand. Genomic Sci. 2015, 10, 73. [CrossRef] [PubMed]

13. Hawumba, J.F.; Theron, J.; Brözel, V.S. Thermophilic Protease-Producing Geobacillus from Buranga Hot Springs in Western Uganda. Curr. Microbiol. 2002, 45, 144-150. [CrossRef] [PubMed]

14. Maugeri, T.L.; Gugliandolo, C.; Caccamo, D.; Stackebrandt, E. Three novel halotolerant and thermophilic Geobacillus strains from shallow marine vents. Syst. Appl. Microbiol. 2002, 25, 450-455. [CrossRef] [PubMed]

15. Zahoor, S.; Javed, M.M.; Babarl, M.E. Characterization Of A Novel Hydrolytic Enzyme Producing Thermophilic Bacterium Isolated From The Hot Spring Of Azad Kashmir-Pakistan. Brazilian Arch. Biol. Technol. 2016, 59. [CrossRef]

16. Asha, B.; Palaniswamy, M. Optimization of alkaline protease production by Bacillus cereus FT 1 isolated from soil. J. Appl. Pharm. Sci. 2018.

17. Saxena, A.; Yadav, A.N.; Rajawat, M.; Kaushik, R.; Kumar, R.; Kumar, M.; Prasanna, R.; Shukla, L. Microbial Diversity of Extreme Regions: An Unseen Heritage and Wealth. Indian J. Plant Genet. Resour. 2016, $29,246$. [CrossRef]

18. Sahay, H.; Yadav, A.N.; Singh, A.K.; Singh, S.; Kaushik, R.; Saxena, A.K. Hot springs of Indian Himalayas: Potential sources of microbial diversity and thermostable hydrolytic enzymes. 3 Biotech 2017, 7, 118. [CrossRef]

19. Cripps, R.E.; Eley, K.; Leak, D.J.; Rudd, B.; Taylor, M.; Todd, M.; Boakes, S.; Martin, S.; Atkinson, T. Metabolic engineering of Geobacillus thermoglucosidasius for high yield ethanol production. Metab. Eng. 2009, 11, 398-408. [CrossRef]

20. Lin, P.P.; Rabe, K.S.; Takasumi, J.L.; Kadisch, M.; Arnold, F.H.; Liao, J.C. Isobutanol production at elevated temperatures in thermophilic Geobacillus thermoglucosidasius. Metab. Eng. 2014, 24, 1-8. [CrossRef]

21. Zeigler, D.R. The Geobacillus paradox: Why is a thermophilic bacterial genus so prevalent on a mesophilic planet? Microbiology 2014, 160, 1-11. [CrossRef] [PubMed]

22. Cui, H.; Yang, M.; Wang, L.; Xian, C.J. Identification of a New Marine Bacterial Strain SD8 and Optimization of Its Culture Conditions for Producing Alkaline Protease. PLoS ONE 2015, 10, e0146067. [CrossRef] [PubMed]

23. Akhavan Sepahy, A.; Jabalameli, L. Effect of Culture Conditions on the Production of an Extracellular Protease by Bacillus sp. Isolated from Soil Sample of Lavizan Jungle Park. Enzym. Res. 2011, 2011, 1-7.

24. Chan, C.S.; Chan, K.-G.; Tay, Y.-L.; Chua, Y.-H.; Goh, K.M. Diversity of thermophiles in a Malaysian hot spring determined using 16S rRNA and shotgun metagenome sequencing. Front. Microbiol. 2015, 6. [CrossRef] [PubMed]

25. McDonald, C.E.; Chen, L.L. The Lowry modification of the Folin reagent for determination of proteinase activity. Anal. Biochem. 1965, 10, 175-177. [CrossRef]

26. Buddingh, G.J. Bergey's Manual of Determinative Bacteriology. Am. J. Trop. Med. Hyg. 1975, $24,550$. [CrossRef]

27. Waterhouse, A.M.; Procter, J.B.; Martin, D.M.A.; Clamp, M.; Barton, G.J. Jalview Version 2-a multiple sequence alignment editor and analysis workbench. Bioinformatics 2009, 25, 1189-1191. [CrossRef]

28. Sinha, R.; Khare, S.K. Characterization of detergent compatible protease of a halophilic Bacillus sp. EMB9: Differential role of metal ions in stability and activity. Bioresour. Technol. 2013, 145, 357-361. [CrossRef] 
29. Nazina, T.N. Geobacillus gargensis sp. nov., a novel thermophile from a hot spring, and the reclassification of Bacillus vulcani as Geobacillus vulcani comb. nov. Int. J. Syst. Evol. Microbiol. 2004, 54, 2019-2024. [CrossRef]

30. Romano, I.; Poli, A.; Lama, L.; Gambacorta, A.; Nicolaus, B. Geobacillus thermoleovorans subsp. stromboliensis subsp. nov., isolated from the geothermal volcanic environment. J. Gen. Appl. Microbiol. 2005, 51, 183-189. [CrossRef]

31. Obeidat, M.; Khyami-Horani, H.; Al-Zoubi, A. Isolation, characterization, and hydrolytic activities of Geobacillus species from Jordanian hot springs. Afr. J. Biotechnol. 2012, 11.

32. Cha, M.; Chambliss, G.H. Cloning and sequence analysis of the heat-stable acrylamidase from a newly isolated thermophilic bacterium, Geobacillus thermoglucosidasius AUT-01. Biodegradation 2013. [CrossRef]

33. Sun, L.; Huang, D.; Zhu, L.; Zhang, B.; Peng, C.; Ma, T.; Deng, X.; Wu, J.; Wang, W. Novel thermostable enzymes from Geobacillus thermoglucosidasius W-2 for high-efficient nitroalkane removal under aerobic and anaerobic conditions. Bioresour. Technol. 2019. [CrossRef] [PubMed]

34. Espina, G.; Eley, K.; Pompidor, G.; Schneider, T.R.; Crennell, S.J.; Danson, M.J. A novel $\beta$-xylosidase structure from Geobacillus thermoglucosidasius: The first crystal structure of a glycoside hydrolase family GH52 enzyme reveals unpredicted similarity to other glycoside hydrolase folds. Acta Crystallogr. Sect. D Biol. Crystallogr. 2014, 70, 1366-1374. [CrossRef] [PubMed]

35. Szeker, K.; Zhou, X.; Schwab, T.; Casanueva, A.; Cowan, D.; Mikhailopulo, I.A.; Neubauer, P. Comparative investigations on thermostable pyrimidine nucleoside phosphorylases from Geobacillus thermoglucosidasius and Thermus thermophilus. J. Mol. Catal. B Enzym. 2012, 84, 27-34. [CrossRef]

36. Castagnaro, A. Overexpression and Characterization of a Laccase from Geobacillus thermoglucosidasius; University New Hampshire: Durham, NH, USA, 2014.

37. Dissanayaka, D.; Rathnayake, I.V.N. Effect of Temperature, pH, Carbon and Nitrogen Sources on Extracellular Protease Production by Four Geobacillus Species Isolated from Maha Oya Geothermal Springs in Sri Lanka. Appl. Microbiol. Open Access 2019, 5, 1-7.

38. Chen, X.-G.; Stabnikova, O.; Tay, J.-H.; Wang, J.-Y.; Tay, S.T.-L. Thermoactive extracellular proteases of Geobacillus caldoproteolyticus, sp. nov., from sewage sludge. Extremophiles 2004, 8, 489-498. [CrossRef]

39. Nielsen, J.; Villadsen, J. Bioreaction Engineering Principles; Springer: Boston, MA, USA, 1994; ISBN 978-1-4757-4647-1.

40. Shanthakumari, A.R.; Boominathan, M. Studies on screening of Bacillus sp. for Protease Production. Int. J. Theor. Appl. Sci. 2017, 9, 294-299.

41. Ward, O.P.; Moo-Young, M. Thermostable enzymes. Biotechnol. Adv. 1988, 6, 39-69. [CrossRef]

42. Chakravorty, D.; Patra, S. Attaining Extremophiles and Extremolytes: Methodologies and Limitations. In Extremophiles; John Wiley \& Sons, Inc.: Hoboken, NJ, USA, 2012; pp. 29-74. ISBN 9781118103005.

43. Margaryan, A.; Shahinyan, G.; Hovhannisyan, P.; Panosyan, H.; Birkeland, N.-K.; Trchounian, A. Geobacillus and Anoxybacillus spp. from Terrestrial Geothermal Springs Worldwide: Diversity and Biotechnological Applications; Springer: Singapore, 2018; pp. 119-166.

44. Thebti, W.; Riahi, Y.; Belhadj, O. Purification and Characterization of a New Thermostable, Haloalkaline, Solvent Stable, and Detergent Compatible Serine Protease from Geobacillus toebii Strain LBT 77. BioMed Res. Int. 2016, 2016, 1-8. [CrossRef]

45. Khusro, A. One Factor at A Time based optimization of protease from poultry associated Bacillus licheniformis. J. Appl. Pharm. Sci. 2016, 088-095. [CrossRef]

46. Vonothini, G.; Murugan, M.; Sivakumar, K.; Sudha, S. Optimization of protease production by an Actinomycete Strain, PS-18A isolated from an estuarine shrimp pond. Afr. J. Biotechnol. 2008.

47. Derekova, A.; Mandeva, R.; Kambourova, M. Phylogenetic diversity of thermophilic carbohydrate degrading bacilli from Bulgarian hot springs. World J. Microbiol. Biotechnol. 2008, 24, 1697-1702. [CrossRef]

48. Frankena, J.; van Verseveld, H.W.; Stouthamer, A.H. A continuous culture study of the bioenergetic aspects of growth and production of exocellular protease in Bacillus licheniformis. Appl. Microbiol. Biotechnol. 1985, 22, 169-176. [CrossRef]

49. Kole, M.M.; Draper, I.; Gerson, D.F. Production of protease by bacillus subtilis using simultaneous control of glucose and ammonium concentrations. J. Chem. Technol. Biotechnol. 2007, 41, 197-206. [CrossRef]

50. Bhunia, B.; Basak, B.; Dey, A. A review on production of serine alkaline protease by Bacillus spp. J. Biochem. Technol. 2012, 3, 448-457. 
51. Malathi, S.; Chakraborty, R. Production of Alkaline Protease by a New Aspergillus flavus Isolate under Solid-Substrate Fermentation Conditions for Use as a Depilation Agent. Appl. Environ. Microbiol. 1991, 57, 712-716. [CrossRef] [PubMed]

52. Tsuchiya, K.; Sakashita, H.; Nakamura, Y.; Kimura, T. Production of Thermostable Alkaline Protease by Alkalophilic Thermoactinomyces sp. HS682. Agric. Biol. Chem. 1991, 55, 3125-3127. [CrossRef]

53. Phadatare, S.U.; Deshpande, V.V.; Srinivasan, M.C. High activity alkaline protease from Conidiobolus coronatus (NCL 86.8.20): Enzyme production and compatibility with commercial detergents. Enzym. Microb. Technol. 1993, 15, 72-76. [CrossRef]

54. Yang, S.-H.; Cho, J.-K.; Lee, S.-Y.; Abanto, O.D.; Kim, S.-K.; Ghosh, C.; Lim, J.-S.; Hwang, S.-G. Isolation and Characterization of Novel Denitrifying Bacterium Geobacillus sp. SG-01 Strain from Wood Chips Composted with Swine Manure. Asian-Australas. J. Anim. Sci. 2013, 26, 1651-1658. [CrossRef] [PubMed]

55. Çelik, S.Y.; Demir, N.; Demir, Y.; Adiguzel, A.; Gulluce, M. Production of pectin lyase from Geobacillus pallidus p26, purification, characterization and fruit juice application. Acta Chim. Slovaca 2014, 7, 57-63. [CrossRef]

56. Kalwasińska, A.; Jankiewicz, U.; Felföldi, T.; Burkowska-But, A.; Swiontek Brzezinska, M. Alkaline and Halophilic Protease Production by Bacillus luteus H11 and its Potential Industrial Applications. Food Technol. Biotechnol. 2018, 56. [CrossRef] [PubMed]

57. Van den Burg, B. Extremophiles as a source for novel enzymes. Curr. Opin. Microbiol. 2003, 6, $213-218$. [CrossRef]

58. Sharma, K.M.; Kumar, R.; Panwar, S.; Kumar, A. Microbial alkaline proteases: Optimization of production parameters and their properties. J. Genet. Eng. Biotechnol. 2017, 15, 115-126. [CrossRef] [PubMed]

59. Hidayat, M.Y.; Saud, H.M.; Samsudin, A.A. Isolation and Characterisation of Sulphur Oxidizing Bacteria Isolated from Hot Spring in Malaysia for Biological Deodorisation of Hydrogen Sulphide in Chicken Manure. Media Peternak. 2017, 40, 178-187. [CrossRef]

60. Prakasham, R.S.; Rao, C.S.; Sarma, P.N. Green gram husk-An inexpensive substrate for alkaline protease production by Bacillus sp. in solid-state fermentation. Bioresour. Technol. 2006, 97, 1449-1454. [CrossRef]

61. Sattar Qureshi, A.; Aqeel Bhutto, M.; Khushk, I.; Umar Dahot, M. Optimization of cultural conditions for protease production by Bacillus subtilis EFRL 01. Afr. J. Biotechnol. 2011.

Sample Availability: Samples of the compounds are available from the authors.

(C) 2020 by the authors. Licensee MDPI, Basel, Switzerland. This article is an open access article distributed under the terms and conditions of the Creative Commons Attribution (CC BY) license (http://creativecommons.org/licenses/by/4.0/). 